\title{
Eolian chronology reveals causal links between tectonics, climate, and erg generation
}

Shlomy Vainer ( $\square$ shlomy.vainer@mail.huji.ac.il)

University of Lausanne

Ari Matmon

Hebrew University of Jerusalem

Yoav Ben Dor

Hebrew University of Jerusalem https://orcid.org/0000-0002-5345-0297

Eric Verrecchia

University of Lausanne

Georges Aumaitre

ASTER, CEREGE

\section{Article}

Keywords: climate change, eolian activity, aridification, Kalahari Erg

Posted Date: September 11th, 2021

DOI: https://doi.org/10.21203/rs.3.rs-801542/v1

License: (c) (1) This work is licensed under a Creative Commons Attribution 4.0 International License. Read Full License

Version of Record: A version of this preprint was published at Nature Communications on September 29th, 2022. See the published version at https://doi.org/10.1038/s41467-022-33316-7. 
1 Eolian chronology reveals causal links between tectonics, climate, and erg generation

\section{Abstract}

3 The onset and intensification of eolian activity mark climatic transitions that promote wide-scale aridification, recorded by the generation and preservation of massive sand deposits. Evaluating the impact and implications of such repositories on Earth systems requires knowledge about the timing of their emplacement and the mechanisms responsible for their generation, which remain highly uncertain. Here we provide time constraints for the establishment of the Kalahari Erg, which is the largest continuous body of sand on Earth. We apply cosmogenic nuclide dating of sand from the Kalahari Desert combined with numerical modeling to determine when sand was introduced into the interior of southern Africa. Through the consideration of several scenarios, we show that major events of eolian sand transport and accumulation occurred between $\sim 2.5$ and $1 \mathrm{Myr}$ ago. This substantial activity, which significantly altered environmental settings, corresponds to regional, continental, and global scale morphotectonic and climatic changes that contributed to the mass production and widespread dispersion of sand. These changes substantially altered existing habitats, thus constituting a crucial milestone for hominin evolution and migration throughout the African continent during the Pleistocene.

\section{Main}

Eolian sand deposits cover $\sim 20 \%$ of the world's drylands and have been shown to be linked with and record substantial changes in terrestrial environments (Thomas and Wiggs, 2008). The instigation of eolian activity in the largest deserts of the world was suggested to mark the onset or significant increase in continental-scale aridity (Stokes et al., 1997; Schuster et al., 2006; Sun et al., 2006; Fujioka et al., 2009). However, the simplified association between periods of increased eolian activity and their paleoclimatic interpretation has been questioned due to (1) the interplay of numerous variables, such as wind energy and direction, the type and distribution of vegetation cover, and sediment generation and supply, all govern eolian dynamics and have contrasting effects, and (2) incoherent basin-scale chronological correlations of both eolian and non-eolian proxies (Chase, 2009; Thomas and Bailey, 2017; Lukich and Ecker, 2021). Therefore, establishing a robust chronological framework in an area where the paleoenvironmental conditions are sufficiently constrained is crucial for disentangling the effects of bedrock erosion and sand generation, its transportation into long- or short-term storage sites and its ensuing deposition or dispersion, within the natural context in which each of these processes occurs. Understanding these relationships is essential for unravelling which mechanisms control eolian landforms and processes and to estimate to which level each of the forcings governs eolian dynamics during climatic changes (Thomas and Wiggs, 2008). 
In this paper, we combine cosmogenic nuclides-based techniques to reconstruct the chronological framework of eolian sand activity at the million-year scale in the arid sector of the largest body of sand on Earth that is situated in southern Africa (i.e., the Kalahari Erg, Partridge, 1993). By comparing our results with independently established proxies and published timeframes of regional and global climatic and environmental shifts, we identify possible triggers causing eolian vitality or dormancy. Furthermore, we point to the specific combination of conditions that would facilitate the formation and expansion of eolian realms as well as the implications of the irruption of massive sand deposits on landforms and habitats.

\section{Sand as a climatic indicator in southern Africa}

The southern part of the African continent lies within a pronounced rainfall gradient attributed to differences in sea surface temperatures of its bordering oceans (Fig. 1a). Moisture influx into the subcontinent is primarily inhibited by the northward-flowing cold Benguela Current that borders its western coastline. The marine record of the Southeast Atlantic that preserves the chronology of the Southern Hemisphere glaciation and the development of the Benguela Current provides a general timeframe of key climatic fluctuations on the western continental margins (Marlow et al., 2000). At the eastern boundary, where climate has developed along a trajectory different than the continental interior (Ecker et al., 2018), only 30\% of the rift-filling lacustrine archives record climate changes (Olaka et al., 2010). An inland chronological link between key shifts in climatic and environmental conditions is restricted to the near-shore sediments of the Namib Desert (Ségalen et al., 2006; Vermeesch et al., 2010), due to the sparsity of continuous terrestrial records in southern Africa (Chase, 2009; Thomas and Bailey, 2017). Thus, the chronology of the geomorphological response of the main continental portion remains poorly constrained (Partridge, 1993).

The extensive sand cover of the Kalahari Basin (Fig. 1a) provides the major regional repository for Quaternary environmental conditions in southern Africa (Chase, 2009). However, direct dating of eolian sand transport and deposition at the million-year timescale in the Kalahari is hampered by the lack of suitable sites and chronometers (Bateman et al., 2003; Matmon et al., 2015; Vainer et al., 2018a). This had resulted in a controversy concerning the antiquity of regional sand deposits, which in turn led to substantially varied estimations of their initial production and subsequent distribution, ranging over tens of millions of years (Lancaster, 1981; Partridge, 1993; Goudie, 2009).

We measured the concentrations of ${ }^{26} \mathrm{Al}$ and ${ }^{10} \mathrm{Be}$ in two sets of samples from the Kalahari Desert to provide more realistic estimates on the timing of their transport and emplacement following detachment from bedrock (Figs 1a,b): (1) fourteen samples of surficial sand that were collected along a $600 \mathrm{~km}$ transect, and (2) six samples collected along a depth profile of buried sandstones in the 
southwestern Kalahari. The surficial sand samples were numerically modelled by simulating their mobilization using the Cosmolian program (Vainer and Ben Dor, 2021). Simulations in which modeled concentrations of ${ }^{26} \mathrm{Al}$ and ${ }^{10} \mathrm{Be}$ simultaneously matched their measured values are considered as plausible transportation paths, and their duration is interpreted as the time that grains spent in eolian transport (i.e., eolian residence time; Vainer et al., 2018a). Because the array of possible environmental parameters employed within the model resulted in several solutions, weighted mean eolian residence times are calculated from 36 scenarios in which agreement between simulated and measured radionuclides was achieved (Fig. 2; Supplementary Data S1). The buried sandstone samples were analyzed by employing cosmogenic nuclide burial dating to determine when the sand was deposited (Granger et al., 1997; Vermeesch et al., 2010; Matmon et al., 2015). We report the intermediate age between two end-member burial ages based on possible pre-burial ${ }^{26} \mathrm{Al} /{ }^{10} \mathrm{Be}$ values (Fig. 1b).

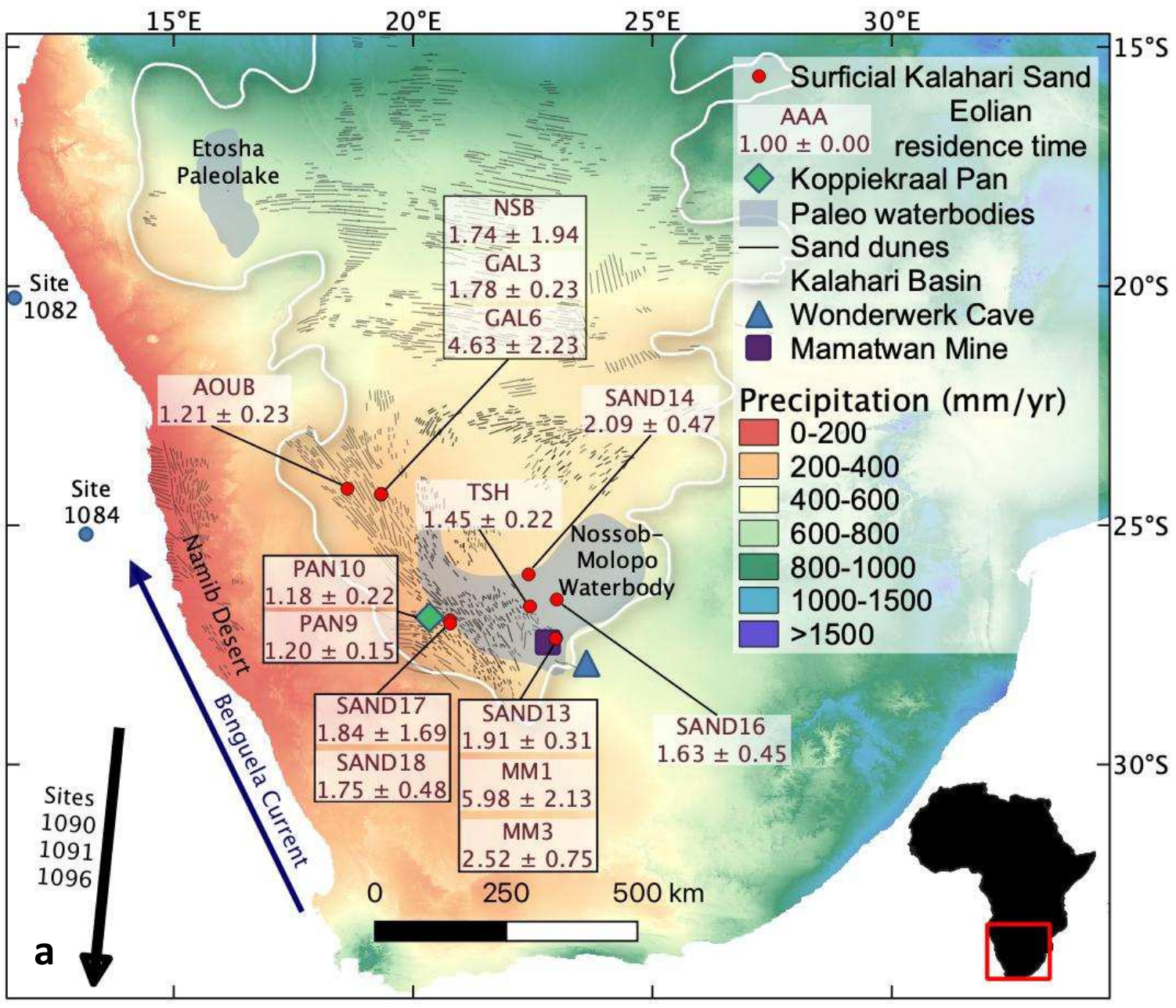




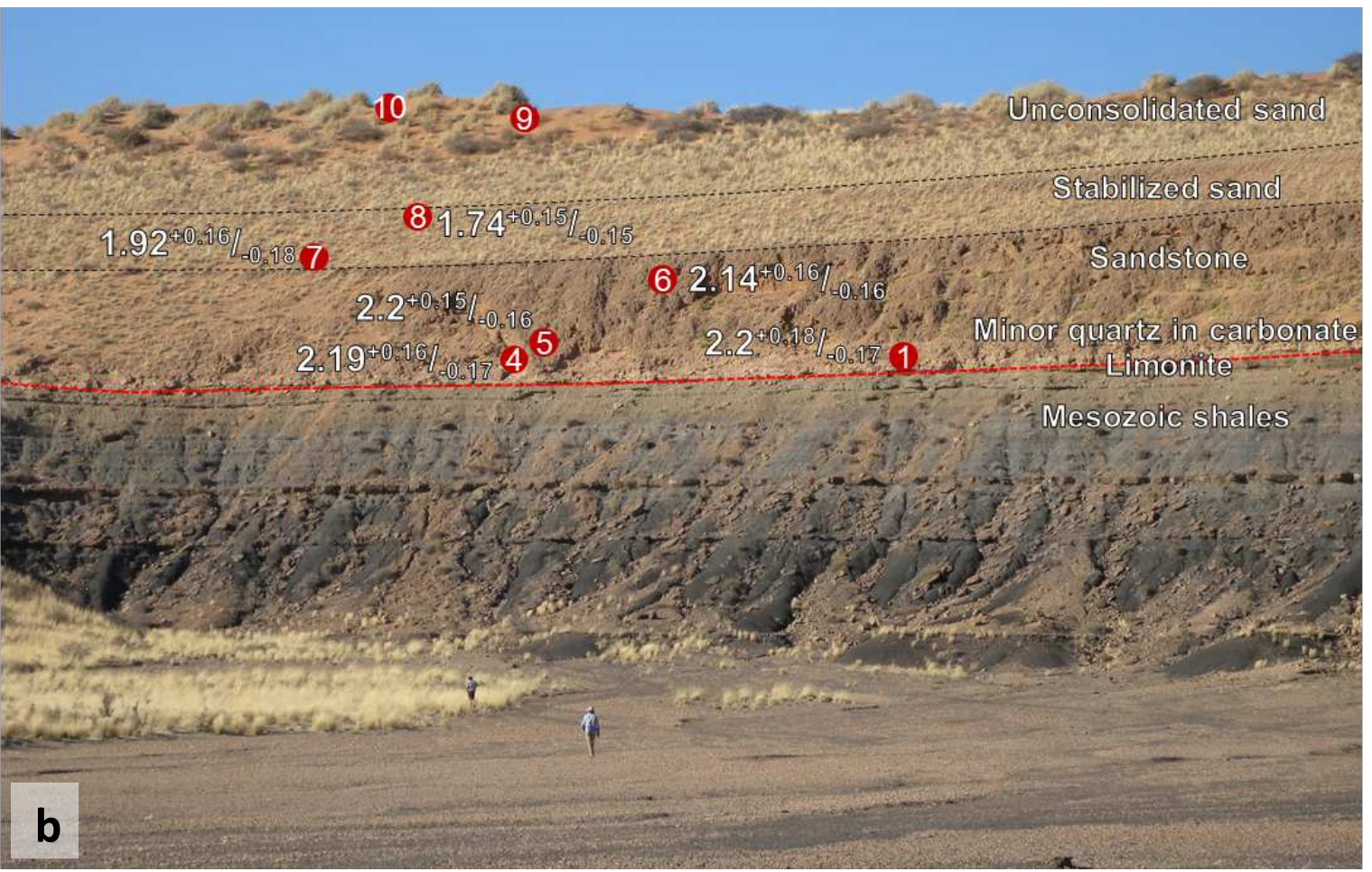

Figure 1. Eolian chronology of the Kalahari Desert Sand. (a) Locations of sand samples and sites mentioned in the text are superimposed on the modern precipitation map of southern Africa (www.worldclim.org). Eolian residence time is the weighted average of the simulated duration in which agreement between simulated and measured radionuclides was achieved and is marked with a black line in Fig. 2. Burial ages (reported in Ma with $1 \sigma$ uncertainty) were calculated assuming pre-burial ${ }^{26} \mathrm{Al} /{ }^{10} \mathrm{Be}$ between 5.03 and 5.15 (estimated iteratively after Granger et al., 1997). Inset: The red rectangle depicts the area of the main figure within the African continent. (b) A $60 \mathrm{~m}$ thick exposure at the northeastern wall of Koppieskraal Pan (see location in Fig. 1a) where $\sim 40 \mathrm{~m}$ of consolidated Kalahari Sand overlies Mesozoic shales of the Karoo supergroup. Burial ages (reported in Ma with $1 \sigma$ uncertainty) were calculated assuming pre-burial ${ }^{26} \mathrm{Al} /{ }^{10} \mathrm{Be}$ between 5.56 and 5.79 (estimated iteratively after Granger et al., 1997). Numbers in red circles correspond to the sample's serial number in the supplementary data.

\section{Chronology of eolian activity and contemporaneous environmental settings}

The Eolian residence time of surficial sand is clustered into a distinct timespan, implying that sands in the Kalahari Desert were formed between $\sim 2.5$ and $1 \mathrm{Ma}$ (Fig. 1a). Probability density plots of simulations that were carried out assuming the lowest erosion rate (representing the currently hyperarid climate) deviate from the general pattern constructed by the rest of the scenarios (Fig. 2). This affirms that at least partly, sand arrived from sources characterized by higher erosion rates than today, due to higher elevation or more humid climate at the time of sand disengagement (Vainer et al., 2018b; Garzanti, E., Pastore, G., Stone, A., Vainer, S., Vermeesch, P., Resentini, A., In review). Burial ages signify that deposition at Koppieskraal Pan took place within a narrower time span, i.e. between 2.2 and $1.7 \mathrm{Ma}$ (Figure $1 \mathrm{~b}$ ), which is in agreement with the independently determined timeframe for the deposition of the Kalahari Sand: maximum age of $4 \pm 1 \mathrm{Ma}$ that was estimated from the youngest fossils of the desiccated Etosha Paleolake that underlie Kalahari Sand (Miller et al., 2010), and a 
minimum age of $1 \mathrm{Ma}$ for the burial of fluvial deposits that underlie eolian sand in Mamatwan Mine (Matmon et al., 2015; Fig. 1a).

These results coincide with several events that could have impacted the production and transport of sand (Fig. 3). During the end of the Pliocene and the Early Pleistocene, the landscape responded to vertical crustal movements that caused substantial uplift along several structural axes in southern Africa (Moore et al., 2012; Vainer et al., 2018b; Vainer et al., 2020). The increased relief was suggested to trigger the creation of the Kalahari Erg (Partridge, 1998), as it would have favored the production of detritus through the dissection of the deformed elevated surfaces, while erosion was enhanced by chemical weathering due to the warmer south Atlantic Ocean waters (Marlow et al., 2000). Accordingly, massive flattening, due to weathering and erosion, characterizes the elevated topography (Partridge, 1998).

The uplifted terrains altered the climatic conditions in the continental interior by blocking oceanderived moisture, thus promoting sand distribution. This regional effect was amplified by transitions in global climate dynamics (Lisiecki and Raymo, 2007), as inferred from the response of $\delta^{18} \mathrm{O}$ in benthic foraminifera in high latitudes to solar forcing (Ravelo et al., 2004). A pronounced climatic shift is recorded at ODP sites 1091 and 1096, which are located 2000-3000 km south of our study sites, where increased cooling and changes in heat transport is observed between 3.2-2.6 Ma (McKay et al., 2012), as well as increased dust deposition at $2.7 \mathrm{Ma}$ (site 1090, Martínez-Garcia et al., 2011). Indeed, a multiproxy compilation of records offshore the Namib Desert (site 1084) demonstrates that the cooling trend at the south Atlantic propagated northwards between 3.2 and 1.0 Ma (Marlow et al., 2000).

The climate deterioration escalated between 1.9 and $1.7 \mathrm{Ma}$, when variations in biogenic silica assemblages in the Southern Ocean occurred (Cortese and Gersonde, 2008). During this period, deposition at Koppieskraal Pan took place, while a second peak of dust flux in the Southern Ocean accumulated in site 1090 (Martínez-Garcia et al., 2011). The continuation of aridification and recycling of existent sediments (rather than the production of new material through bedrock erosion) is further manifested by the widespread coverage of pans in the southwestern Kalahari. Their presence implies sediment starvation and inefficiency of current conditions to dissolve carbonates, silicates, and salts, both signify the lack of sufficient moisture (Stone, 2021). 

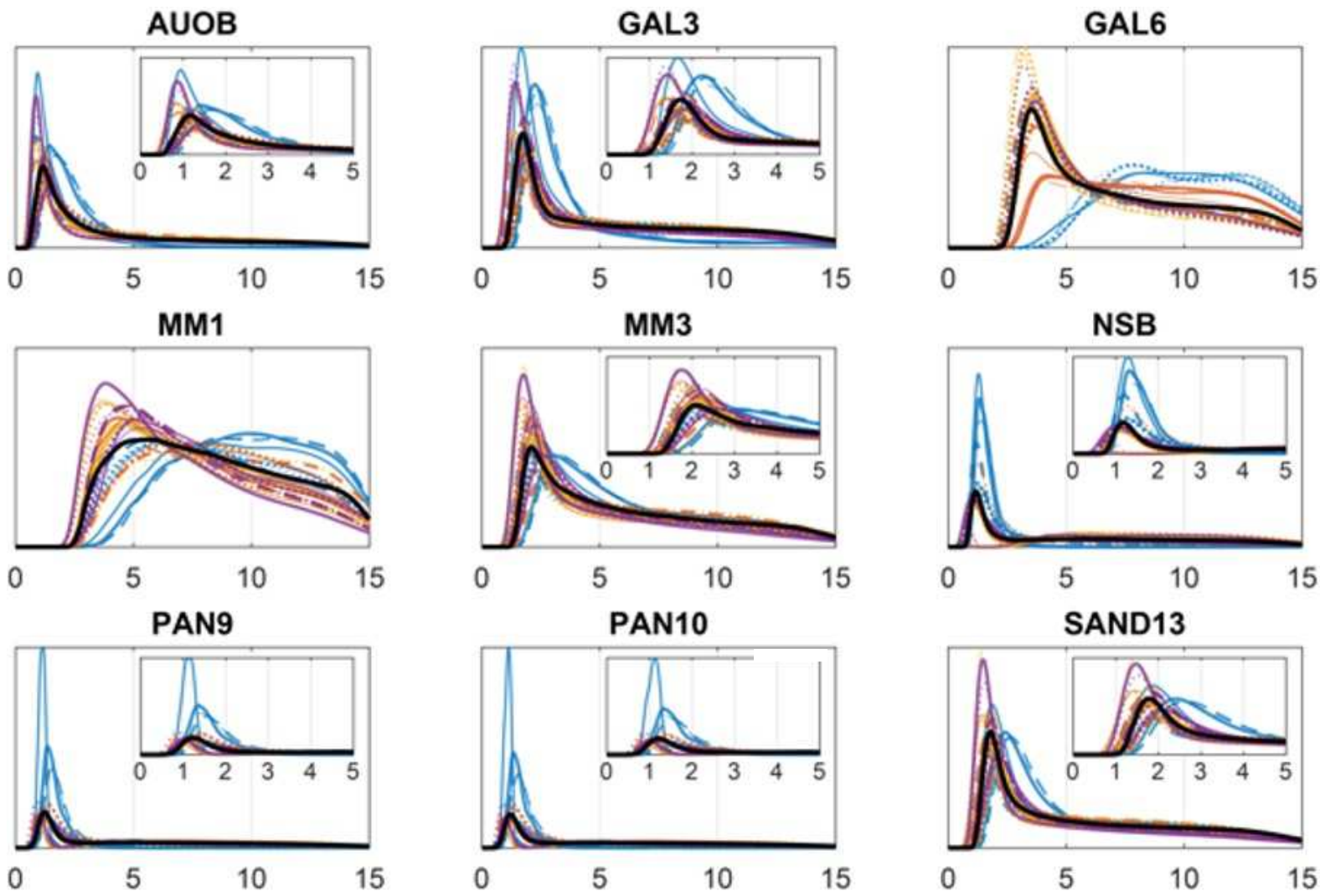

SAND13
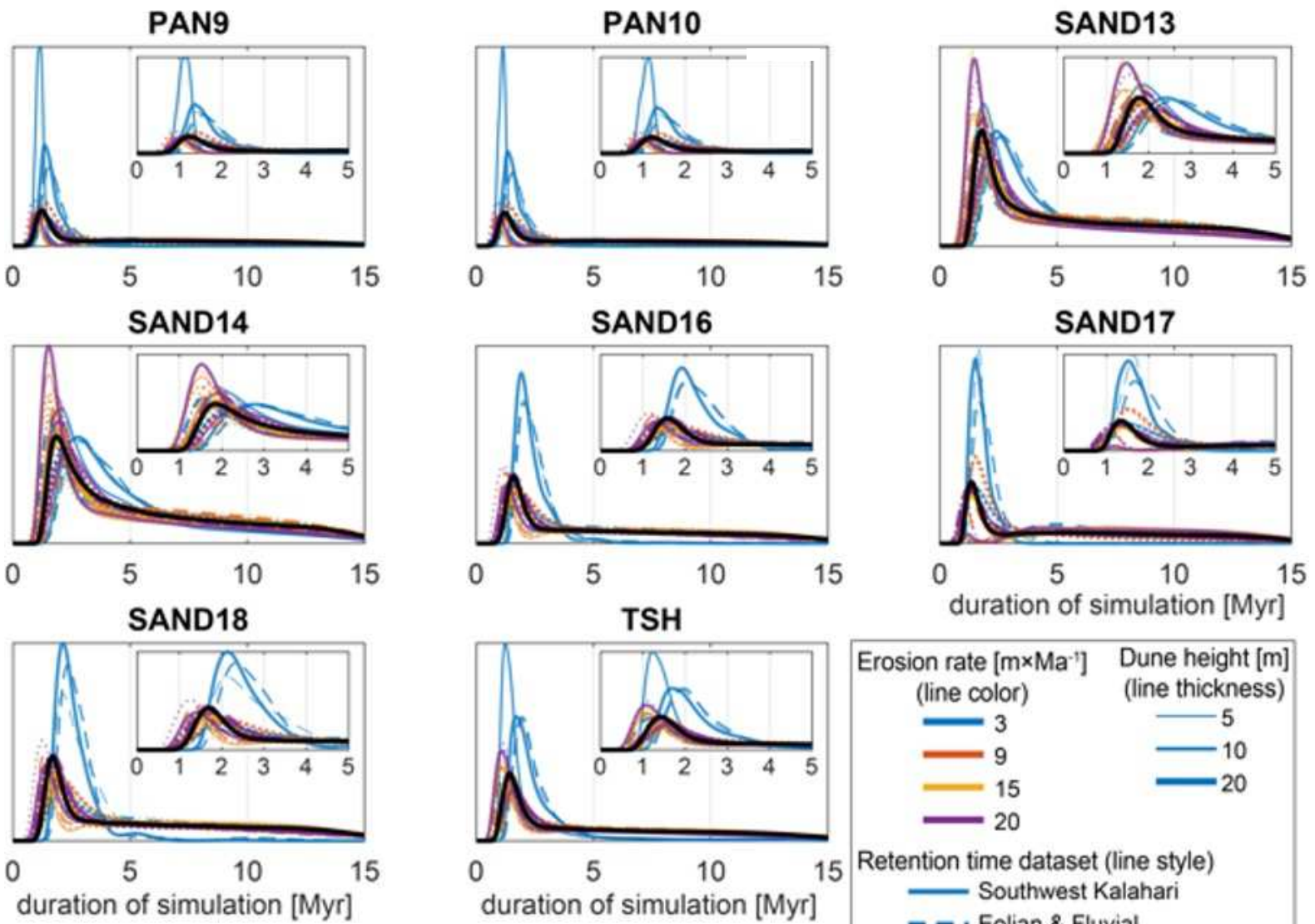

Figure 2. Probability density functions (PDF's) of simulations carried out using the Cosmolian program (Vainer and Ben Dor, 2021) in which modelled concentrations of ${ }^{26} \mathrm{Al}$ and ${ }^{10} \mathrm{Be}$ initially matched their measured values in Kalahari Sand samples. Results are the outcome of 10,000 simulations for each of the 36 combinations of parameters representing possible scenarios considered for each sample. These boundary conditions include four paleo-erosion rates, three dune heights, and three datasets of vertical displacement rates (VDR) constructed from luminescence and ${ }^{14} \mathrm{C}$ ages of the Kalahari Sand. In twelve out of fourteen samples, PDF's are clustered into distinct peaks that are ranged within a narrow time span. For each sample, the weighted average of all simulations is shown with a black solid line and its highest probability is interpreted as the eolian residence time. 


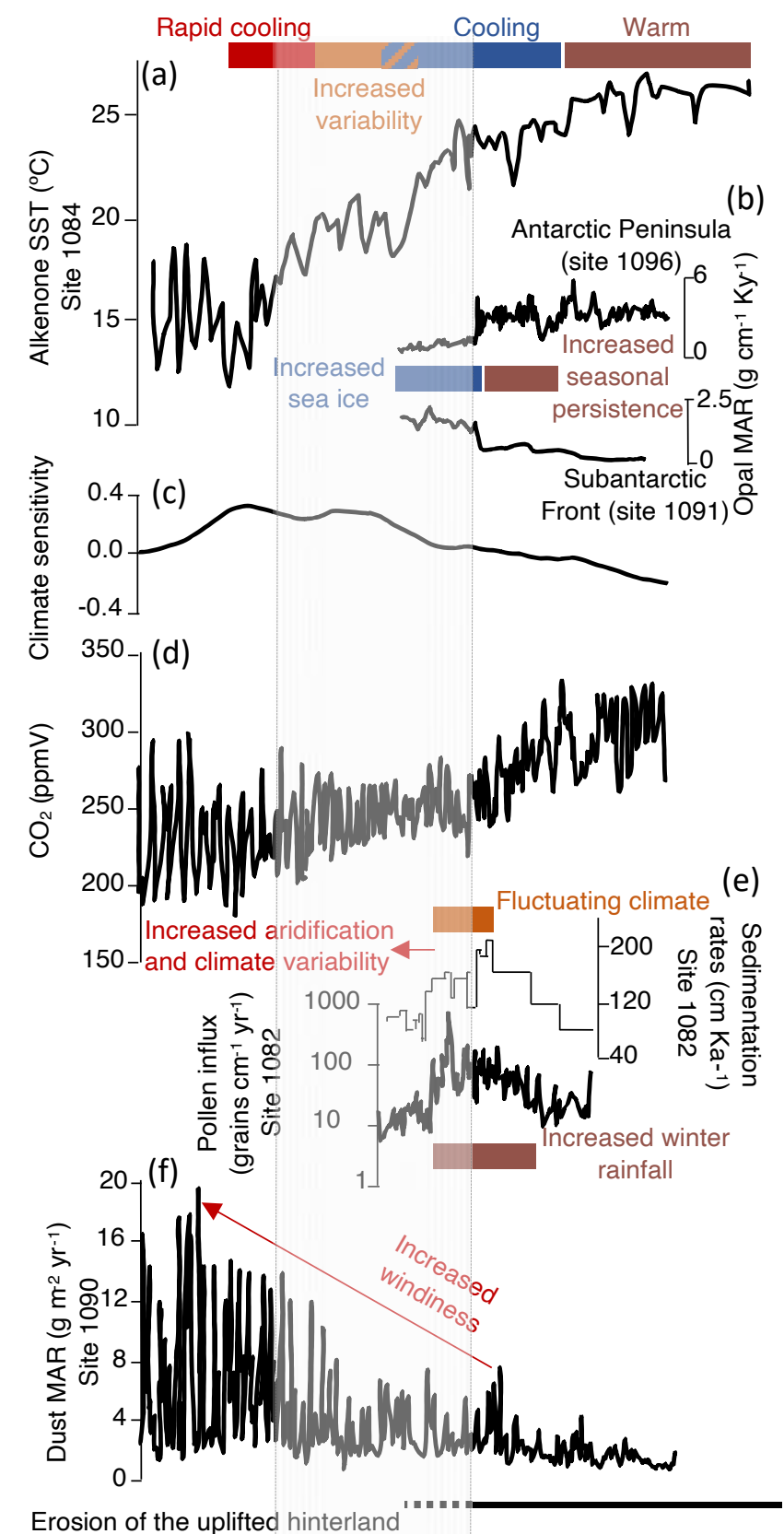

Erosion of the uplifted hinterland

Etosha Paleolake desiccation

II Nossob-Molopo Waterbody desiccation

Filling of the

Wonderwerck Cave IIIIII| ||IIII|

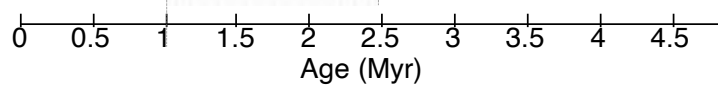

Figure 3. The timing of eolian activity in the Kalahari Desert (shaded gray rectangle) displayed on top of environmental settings and key events in southern Africa and proximate oceans. The text provides interpretation of the records and is colored in accordance with colored bars and arrows. (a) Sea Surface Temperature (SST) record offshore Namibia (ODP site 1084) derived from alkenone unsaturated index $\left(U_{37}^{K \prime}\right)$, which reflects the strengthening of upwelling along the west African margins throughout the Pleistocene (Marlow et al., 2000). (b) Primary productivity based on biogenic opal Mass Accumulation Rates (MAR) shows coeval increase in the Southern Ocean (ODP site 1091) and decrease in the Antarctic Peninsula (ODP site 1096) due to the onset of Antarctic Sea Ice (McKay et al., 2012). (c) Climate sensitivity in high latitudes, calculated as the ratio between the deconvoluted records of the obliquity component of the scaled oxygen isotope and the solar forcing (Ravelo et al., 2004). (d) Reconstructed atmospheric $\mathrm{CO}_{2}$ record showing a decrease below the bioclimatic threshold for the expansion of $C_{4}$ plants at 2.7 Ma (Van de Wal et al., 2011). (e) Sedimentation rates and pollen Influx at ODP Site 1082 indicating a transition from a mixed fluvial and eolian input to predominantly eolian transport at $2.2 \mathrm{Ma}$ (Dupont, 2006). (f) Dust MAR at site 1090 derived from Ti MAR recording increased windiness since $2.7 \mathrm{Ma}$ (Martínez-Garcia et al., 2011).

\section{Triggers of eolian activity and erg formation}

147 The developed orography and climate fluctuations that characterized southern Africa during the late 148 Pliocene and the early Pleistocene were essential for establishing the Kalahari Erg (Partridge, 1998;

149 Trauth et al., 2009). These are expressed by apparently contradicting proxies of humid and arid conditions during the Pliocene-Pleistocene boundary including (1) accelerated denudation and canyon 
incision (van der Wateren and Dunai, 2001) and (2) augmented long-distance transport of eolian silt (Diekmann et al., 2003). The interplay between successive humid and arid conditions taking place within a bimodal topography would have resulted in massive weathering of the elevated margins following by eolian propagation of the sediments by wind within the subsidized basin (RodríguezLópez et al., 2008; Trauth et al., 2009).

Additional sand availability was promoted by the sharp decrease in $\mathrm{CO}_{2}$ levels that began around $3 \mathrm{Ma}$ (Van de Wal et al., 2011), stimulating the dispersion and increasing the density of $\mathrm{C}_{4}$ grass cover during the Pleistocene, when concentrations fell below the $250 \mathrm{ppm}$ threshold (Ecker et al., 2020). This in turn would have facilitated the mobilization of the freshly produced sand, by reducing the tree to grass ratio. Such changes in vegetation communities would have lessened the amount of canopy protection, encouraging wind erosion (Webb et al., 2009; Cerling, 2014). Similar floral adaptions were identified in the near-shore terrestrial vicinity of southwestern Africa, recording extensive grass-rich savannah and semi-arid vegetation since the very early Pleistocene (Dupont, 2006). More inland, vegetation cover in the southern Kalahari Desert was already reduced by $2 \mathrm{Ma}$, as suggested by the reconstructed $C_{3}-C_{4}$ floral assemblage (Ségalen et al., 2007; Ecker et al., 2018). These changes promoted sand transport deep into the heart of the continent throughout the early Pleistocene as recorded by sand preserved in the Wonderwerk Cave (Fig. 1; Matmon et al., 2012, Shaar et al., 2021).

The distribution of unconsolidated sand would have been enhanced by the strengthening of winds due to the expansion of atmospheric convective cells. Such transitions in wind patterns were suggested to follow a major enlargement of ice sheets in the Southern Ocean that started at 3.3 Ma and culminated at 2.7 Ma (Martínez-Garcia et al., 2011; McKay et al., 2012). The onset of glaciation in the Northern Hemisphere, which took place at the same time, is linked with accelerated regolith removal and lowered atmospheric $\mathrm{CO}_{2}$ content between $\sim 2.6$ and $1.5 \mathrm{Ma}$ (Willeit et al., 2019). If the analogous climatic cooling in the Southern Hemisphere was also similarly affected by regolith removal, the eolian dispersion of erosional material was likely intensified by these changes in atmospheric circulation.

\section{The impact of sand dispersion on landforms and habitats}

Mammalian and hominin evolution and their migration in eastern Africa were attributed to the interaction between tectonics and climate variability, especially where the effects of such drivers supported lakes that formed supportive habitats for hominins (Trauth et al., 2010). This approach focuses on the accommodation space and precipitation regime that directly control the formation and extent of waterbodies. However, in sand-dominated terrains, the effect of climate change on the interactions between ground and surface waters is highly transient, since seepage from waterbodies 
to groundwater takes place through most of its bed (Winter, 1999). Moreover, damming of fluvial systems is common in erg-like landscapes (Krapf et al, 2003), thus limiting water transport into geomorphological depressions and the formation of durable lakes within them.

Therefore, the introduction of sand into southern Africa during the early Pleistocene due to tectonic and climatic transitional events had dramatically altered the environment by blanketing the landscape with massive sand deposits, encouraging biota to adapt accordingly. The ecological response to the changing environment is demonstrated by the speciation of near-shore flora and fauna at 2.7-2.2 Ma (Sole et al., 2005; Dupont, 2006) and stable isotopes in fossil eggshells that signify the ongoing desertification from the coast inland which sharply increased at 2 Ma (Ségalen et al., 2006; Senut et al., 2009). More inland, the emplacement of extensive sand deposits resulted in the desiccation of the Nossob-Molopo Waterbody (Fig. 1a) that disappeared around $1 \mathrm{Ma}$, irreversibly altering the landscape for the hominins that densely occupied the area and was probably a vital turning point in their migration path to areas with higher water availability. (Matmon et al., 2015; Vainer et al., 2018b; Ecker et al., 2018).

\section{METHODS}

\section{${ }^{26} \mathrm{Al}$ and ${ }^{10} \mathrm{Be}$ extraction}

Amalgamated sand samples of $\sim 500 \mathrm{gr}$ were sieved in the lab to $250-850 \mu \mathrm{m}$, and purified the quartz to determine in-situ ${ }^{26} \mathrm{Al}$ and ${ }^{10} \mathrm{Be}$ content (Kohl and Nishiizumi, 1992; Supplementary Data S2). The procedure involved sample leaching by aqua regia solution $\left(3: 1\right.$ of $\left.\mathrm{HCl}: \mathrm{HNO}_{3}\right)$ at $50^{\circ} \mathrm{C}$, magnetic separation, and sequential $\mathrm{HF}+\mathrm{HNO}_{3}$ etching. ${ }^{9} \mathrm{Be}$ and ${ }^{27} \mathrm{Al}$ spikes were added prior to quartz digestion in $\mathrm{HF}, \mathrm{HClO}_{4}$, and $\mathrm{HNO}_{3}$ mixture. Aliquots were extracted from the dissolved fraction, one before the addition of the Al carrier and one after, for native Al measurements by ICP-MS at the Hebrew University of Jerusalem. $\mathrm{Al}^{+2}$ and $\mathrm{Be}^{+2}$ were extracted via ion-exchange chromatography and converted to oxides at $750^{\circ} \mathrm{C}$ (Bierman and Caffee, 2001).

Isotopic ratios of oxidized targets were measured by accelerator mass spectrometry at Centre de Recherche et d'Enseignement de Géosciences de l'Environnement (CEREGE), France. All ratios are corrected for AMS facility blanks. AMS blank values for samples SAND13, SAND14, MM1, and MM3 are from Matmon et al. (2015). AMS blank values for all other samples are: ${ }^{26} \mathrm{Al} /{ }^{27} \mathrm{Al}-7.041 * 10^{-12}$; ${ }^{10} \mathrm{Be} /{ }^{9} \mathrm{Be}-6.05^{*} 10^{-12}$. All ratios are corrected for procedural blanks. Procedural blank values range between $3.2 * 10^{-15}$ and $9 * 10^{-16}$ for ${ }^{26} \mathrm{Al} /{ }^{27} \mathrm{Al}$ and between $1.94 * 10^{-15}$ and $7.98^{-15}$ for ${ }^{10} \mathrm{Be} /{ }^{9} \mathrm{Be}$. Each batch of samples was corrected by the value of the corresponding batch blank. 
217 Apparent burial ages were estimated for the detrital quartzose components in one carbonate218 dominated sample and five overlying consolidated sandstone samples at the northeastern margin of the Koppieskraal Pan (Fig. 1; Supplementary Data S1). Three end member, pre-burial, ${ }^{26} \mathrm{Al} /{ }^{10} \mathrm{Be}$ values were considered: 1) a surface production ratio value of 6.75 (Balco et al., 2008), 2) a ratio calculated individually for each sample through iteration (range between 5.03 and 5.79), assuming steady erosion (Granger et l., 1997), and 3) a value estimated from the measured concentrations in current surface samples that overlie the buried samples. At the Koppieskraal Pan, we used the average value of two surface samples, i.e. 4.17, and for GAL6 and GAL3, we used the ratio of the NSB sample of 4.24. The resulting three apparent burial ages, calculated using the MATLAB implementation of Matmon et al. (2015), set the plausible age range for the deposition of sediments. With the assumed pre-burial ratio, ${ }^{26} \mathrm{Al}$ and ${ }^{10} \mathrm{Be}$ concentrations were modeled as the product of build-up during exposure, followed by radionuclide decay and post-burial production by muons, assuming production rates of present-day sample depth (Hidy et al., 2013). Specific nuclide production was estimated using the time-varying scaling scheme (Lifton et al., 2014). Probability density function for each sample age was calculated via chi-squared inversion of a 2D Monte Carlo simulation which generates concentrations as the outcome of nuclide build-up and burial durations.

Eolian residence time for unconsolidated sand was modeled according to several possible scenarios constructed from thirty-six combinations of boundary conditions (Supplementary Data S3) using the Cosmolian program (Vainer and Ben Dor 2021). This program simulates the build-up of ${ }^{26} \mathrm{Al}$ and ${ }^{10} \mathrm{Be}$ through a 2D simulation of dune generation scheme (Vainer et al., 2018a). Erosion rates of 3, 9, $15 \mathrm{~m}$ $\mathrm{Ma}^{-1}$, typical of present African landforms, were used to model pre-eolian concentrations (Bierman and Caffee, 2001). A higher value of $20 \mathrm{~m} \mathrm{Ma}^{-1}$ was also assigned based on our calculations of paleoerosion rates from ${ }^{10} \mathrm{Be}$ concentrations of deeply buried sediments in the study area (Matmon et al., 2015). Three characteristic dune heights $(5,10,20 \mathrm{~m})$ were considered for the simulated amplitude of vertical displacement, and three datasets were used as vertical displacement rates for migrating eolian sand. These datasets are based on the conversion of luminescence and ${ }^{14} \mathrm{C}$ ages of eolian and fluvial deposits in the study area (Lawson and Thomas, 2002; Bateman et al., 2003; Telfer and Thomas, 2007; Telfer, 2011; Hürkamp et al., 2011) into retention times (Vainer et al., 2018a). An additional adjusted dataset was constructed to account for the possible bias stemming from oversampling young and shallow dune deposits by equating the probabilities of the shortest retention periods comprising $90 \%$ of the data to the $10 \%$ longer durations of the dataset (Vainer et al., 2018a). Average production rates were calculated for the catchment area above each sampling area (Wittmann et al., 2020), based on 
modelling results are summarized and presented as the most probable modelled time for convergence between measured and modelled ${ }^{26} \mathrm{Al}$ and ${ }^{10} \mathrm{Be}$ to occur and the percentage of such convergence events for each combination of boundary conditions (Supplementary Data S4).

Because shallowly buried samples could be affected by long periods of stagnancy that are not represented in the datasets used to construct the vertical displacement rates, we constrained our estimation for the duration of eolian vitality of these samples (GAL3, GAL6, MM3) by calculating their burial age as well.

\section{References for methods}

Balco, G., Stone, J.O., Lifton, N.A., Dunai, T.J., 2008. A complete and easily accessible means of calculating surface exposure ages or erosion rates from Be-10 and Al-26 measurements. Quat. Geochronol. 3 (3), 174-195.

Bierman, P.R. and Caffee, M., 2001. Slow rates of rock surface erosion and sediment production across the Namib Desert and escarpment, southern Africa. American Journal of Science, 301(4-5), pp.326-358.

Danielson, J.J. and Gesch, D.B., 2011. Global multi-resolution terrain elevation data 2010 (GMTED2010) (p. 26). US Department of the Interior, US Geological Survey.

Hidy, A.J., Gosse, J.C., Blum, M.D. and Gibling, M.R., 2014. Glacial-interglacial variation in denudation rates from interior Texas, USA, established with cosmogenic nuclides. Earth and Planetary Science Letters, 390, pp.209-221.

Hürkamp, K., Völkel, J., Heine, K., Bens, O., Leopold, M. and Winkelbauer, J., 2011. Late Quaternary environmental changes from aeolian and fluvial geoarchives in the southwestern Kalahari, South Africa: implications for past African climate dynamics. South African Journal of Geology, 114(3-4), pp.459-474.

Lawson, M.P. and Thomas, D.S.G., 2002. Late Quaternary lunette dune sedimentation in the southwestern Kalahari Desert, South Africa: luminescence based chronologies of aeolian activity. Quaternary Science Reviews, 21(7), pp.825-836.

Lifton, N., Sato, T. and Dunai, T.J., 2014. Scaling in situ cosmogenic nuclide production rates using analytical approximations to atmospheric cosmic-ray fluxes. Earth and Planetary Science Letters, 386, pp.149-160.

Kohl, C.P. and Nishiizumi, K., 1992. Chemical isolation of quartz for measurement of in-situ-produced cosmogenic nuclides. Geochimica et Cosmochimica Acta, 56(9), pp.3583-3587.

Telfer, M. W., \& Thomas, D. S. G. (2007). Late Quaternary linear dune accumulation and chronostratigraphy of the southwestern Kalahari: implications for aeolian palaeoclimatic reconstructions and predictions of future dynamics. Quaternary Science Reviews, 26(19-21), 26172630 .

Telfer, M. W. (2011). Growth by extension, and reworking, of a south-western Kalahari linear dune. Earth Surface Processes and Landforms, 36(8), 1125-1135. 
Wittmann, H., Oelze, M., Gaillardet, J., Garzanti, E., \& von Blanckenburg, F. (2020). A global rate of denudation from cosmogenic nuclides in the Earth's largest rivers. Earth-Science Reviews, 204, 103147.

\section{References}

Bateman, M.D., Thomas, D.S. and Singhvi, A.K., 2003. Extending the aridity record of the Southwest Kalahari: current problems and future perspectives. Quaternary International, 111(1), pp.37-49.

Cerling, T. E., 2014. Stable Isotope Evidence for Hominin Environments in Africa. Treatise on Geochemistry, pp.157-167.

Chase, B., 2009. Evaluating the use of dune sediments as a proxy for palaeo-aridity: a southern African case study. Earth-Science Reviews, 93(1-2), pp.31-45.

Cortese, G. and Gersonde, R., 2008. Plio-Pleistocene changes in the main biogenic silica carrier in the Southern Ocean, Atlantic Sector. Marine Geology, 252(3-4), pp.100-110.

Diekmann, B., Fälker, M. and Kuhn, G., 2003. Environmental history of the south-eastern South Atlantic since the Middle Miocene: Evidence from the sedimentological records of ODP Sites 1088 and 1092. Sedimentology, 50(3), pp.511-529.

Dupont, L.M., 2006. Late Pliocene vegetation and climate in Namibia (southern Africa) derived from palynology of ODP Site 1082. Geochemistry, Geophysics, Geosystems, 7(5), doi: 10.1029/2005GC001208.

Ecker, M., Brink, J.S., Rossouw, L., Chazan, M., Horwitz, L.K. and Lee-Thorp, J.A., 2018. The palaeoecological context of the Oldowan-Acheulean in southern Africa. Nature ecology \& evolution, 2(7), pp.1080-1086.

Ecker, M., Kelley, D. and Sato, H., 2020. Modelling the effects of $\mathrm{CO}_{2}$ on $\mathrm{C}_{3}$ and $\mathrm{C}_{4}$ grass competition during the mid-Pleistocene transition in South Africa. Scientific reports, 10(1), pp.1-8.

Fujioka, T., Chappell, J., Fifield, L.K. and Rhodes, E.J., 2009. Australian desert dune fields initiated with Pliocene-Pleistocene global climatic shift. Geology, 37(1), pp.51-54.

Garzanti, E., Pastore, G., Stone, A., Vainer, S., Vermeesch, P., Resentini, A., Provenance of Kalahari Sand: Paleoweathering and recycling in a linked fluvial-aeolian system. Earth-Science Reviews. In review.

Goudie, A., 2009. Namib Sand Sea: large dunes in an ancient desert. In Geomorphological landscapes of the world (pp. 163-169). Springer, Dordrecht.

Granger, D.E., Kirchner, J.W. and Finkel, R.C., 1997. Quaternary downcutting rate of the New River, Virginia, measured from differential decay of cosmogenic 26Al and 10Be in cave-deposited alluvium. Geology, 25(2), pp.107-110. 
Krapf, C.B., Stollhofen, H. and Stanistreet, I.G., 2003. Contrasting styles of ephemeral river systems and their interaction with dunes of the Skeleton Coast erg (Namibia). Quaternary International, 104(1), pp.41-52.

Lancaster, N., 1981. Paleoenvironmental implications of fixed dune systems in Southern Africa. Palaeogeography, Palaeoclimatology, Palaeoecology, 33(4), pp.327-346.

Lisiecki, L.E. and Raymo, M.E., 2007. Plio-Pleistocene climate evolution: trends and transitions in glacial cycle dynamics. Quaternary Science Reviews, 26(1-2), pp.56-69.

Lukich, V., \& Ecker, M. (2021). Pleistocene environments in the southern Kalahari of South Africa. Quaternary International, corrected proof available on line: doi.org/10.1016/j.quaint.2021.03.008.

Marlow, J.R., Lange, C.B., Wefer, G. and Rosell-Melé, A., 2000. Upwelling intensification as part of the Pliocene-Pleistocene climate transition. Science, 290(5500), pp.2288-2291.

Martínez-Garcia, A., Rosell-Melé, A., Jaccard, S.L., Geibert, W., Sigman, D.M. and Haug, G.H., 2011. Southern Ocean dust-climate coupling over the past four million years. Nature, 476(7360), pp.312315.

Matmon, A., Hidy, A.J., Vainer, S., Crouvi, O., Fink, D., Erel, Y., Arnold, M., Aumaître, G., Bourlès, D., Keddadouche, K. and Horwitz, L.K., 2015. New chronology for the southern Kalahari Group sediments with implications for sediment-cycle dynamics and early hominin occupation. Quaternary Research, 84(1), pp.118-132.

Matmon, A., Ron, H., Chazan, M., Porat, N. and Horwitz, L.K., 2012. Reconstructing the history of sediment deposition in caves: A case study from Wonderwerk Cave, South Africa. GSA Bulletin, 124(3-4), pp.611-625.

McKay, R., Naish, T., Carter, L., Riesselman, C., Dunbar, R., Sjunneskog, C., Winter, D., Sangiorgi, F., Warren, C., Pagani, M. and Schouten, S., 2012. Antarctic and Southern Ocean influences on Late Pliocene global cooling. Proceedings of the National Academy of Sciences, 109(17), pp.6423-6428.

Miller, R.M., Pickford, M. and Senut, B., 2010. The geology, palaeontology and evolution of the Etosha Pan, Namibia: Implications for terminal Kalahari deposition. South African Journal of Geology, 113(3), pp.307-334.

Moore, A.E., Cotterill, F.P.D. and Eckardt, F.D., 2012. The evolution and ages of Makgadikgadi palaeo-lakes: consilient evidence from Kalahari drainage evolution south-central Africa. South African Journal of Geology, 115(3), pp.385-413.

Olaka, L.A., Odada, E.O., Trauth, M.H. and Olago, D.O., 2010. The sensitivity of East African rift lakes to climate fluctuations. Journal of Paleolimnology, 44(2), pp.629-644.

Partridge, T.C., 1993. The evidence for Cainozoic aridification in southern Africa. Quaternary International, 17, pp.105-110.

Partridge, T.C., 1998. Of diamonds, dinosaurs and diastrophism: 150 million years of landscape evolution in southern Africa. South African Journal of Geology, 101(3), pp.167-184.

Ravelo, A.C., Andreasen, D.H., Lyle, M., Lyle, A.O. and Wara, M.W., 2004. Regional climate shifts caused by gradual global cooling in the Pliocene epoch. Nature, 429(6989), pp.263-267. 
Rodríguez-López, J.P., Melendez, N., De Boer, P.L. and Soria, A.R., 2008. Aeolian sand sea development along the mid-Cretaceous western Tethyan margin (Spain): erg sedimentology and palaeoclimate implications. Sedimentology, 55(5), pp.1253-1292.

Schuster, M., Duringer, P., Ghienne, J.F., Vignaud, P., Mackaye, H.T., Likius, A. and Brunet, M., 2006. The age of the Sahara Desert. Science, 311(5762), pp.821-821.

Ségalen, L., Lee-Thorp, J.A. and Cerling, T., 2007. Timing of $\mathrm{C}_{4}$ grass expansion across sub-Saharan Africa. Journal of Human Evolution, 53(5), pp.549-559.

Ségalen, L., Renard, M., Lee-Thorp, J. A., Emmanuel, L., Le Callonnec, L., De Rafélis, M., ... \& Melice, J. L. (2006). Neogene climate change and emergence of $C_{4}$ grasses in the Namib, southwestern Africa, as reflected in ratite ${ }^{13} \mathrm{C}$ and ${ }^{18} \mathrm{O}$. Earth and Planetary Science Letters, 244(3-4), 725-734.

Senut, B., Pickford, M. and Ségalen, L., 2009. Neogene desertification of Africa. Comptes Rendus Geoscience, 341(8-9), pp.591-602.

Shaar, R., Matmon, A., Horwitz, L.K., Ebert, Y., Chazan, M., Arnold, M., Aumaître, G., Bourlès, D. and Keddadouche, K., 2021. Magnetostratigraphy and cosmogenic dating of Wonderwerk Cave: New constraints for the chronology of the South African Earlier Stone Age. Quaternary Science Reviews, 259 , p.106907.

Sole, C.L., Scholtz, C.H. and Bastos, A.D., 2005. Phylogeography of the Namib Desert dung beetles Scarabaeus (Pachysoma) MacLeay (Coleoptera: Scarabaeidae). Journal of Biogeography, 32(1), pp.75-84.

Stokes, S., Thomas, D.S. and Washington, R., 1997. Multiple episodes of aridity in southern Africa since the last interglacial period. Nature, 388(6638), pp.154-158.

Stone, A., 2022. Landscape evolution of the Stampriet Transboundary Basin and relation to the groundwater system: the land of duricrusts, pans, dry valleys and dunes, and the relation to the groundwater system. In Landscapes and Landforms of Botswana (pp. 8). Springer Nature, Switzerland. Isbn/Ean 3030861015 / 9783030861018.

Sun, J. and Liu, T., 2006. The age of the Taklimakan Desert. Science, 312(5780), pp.1621-1621.

Thomas, D.S. and Wiggs, G.F., 2008. Aeolian system responses to global change: challenges of scale, process and temporal integration. Earth Surface Processes and Landforms, 33(9), pp.1396-1418.

Thomas, D.S. and Bailey, R.M., 2017. Is there evidence for global-scale forcing of Southern Hemisphere Quaternary desert dune accumulation? A quantitative method for testing hypotheses of dune system development. Earth Surface Processes and Landforms, 42(14), pp.2280-2294.

Trauth, M.H., Larrasoana, J.C. and Mudelsee, M., 2009. Trends, rhythms and events in PlioPleistocene African climate. Quaternary Science Reviews, 28(5-6), pp.399-411.

Trauth, M.H., Maslin, M.A., Deino, A.L., Junginger, A., Lesoloyia, M., Odada, E.O., Olago, D.O., Olaka, L.A., Strecker, M.R. and Tiedemann, R., 2010. Human evolution in a variable environment: the amplifier lakes of Eastern Africa. Quaternary Science Reviews, 29(23-24), pp.2981-2988.

Vainer, S., Ben Dor, Y. and Matmon, A., 2018a. Coupling cosmogenic nuclides and luminescence dating into a unified accumulation model of aeolian landforms age and dynamics: The case study of the Kalahari Erg. Quaternary Geochronology, 48, pp.133-144. 
402 Vainer, S., Erel, Y. and Matmon, A., 2018b. Provenance and depositional environments of

403 Quaternary sediments in the southern Kalahari Basin. Chemical Geology, 476, pp.352-369.

404 Vainer, S., Matmon, A., Erel, Y., Hidy, A.J., Crouvi, O., De Wit, M., Geller, Y. and ASTER Team, 2021.

405 Landscape responses to intraplate deformation in the Kalahari constrained by sediment provenance

406 and chronology in the Okavango Basin. Basin Research, 33(2), pp.1170-1193.

407 Vainer, S \& Ben Dor, Y, 2021. The Cosmolian program for simulating aeolian dynamics and its

408 application to central Australia. Earth Surface Processes and Landforms, 46 (9), pp. 1631-1639.

409 Van de Wal, R.S.W., De Boer, B., Lourens, L., Köhler, P. and Bintanja, R., 2011. Reconstruction of a 410 continuous high-resolution $\mathrm{CO}_{2}$ record over the past 20 million years. Climate of the Past, 7, pp.1459-

4111469.

412 Van der Wateren, F.M. and Dunai, T.J., 2001. Late Neogene passive margin denudation history 413 cosmogenic isotope measurements from the central Namib desert. Global and Planetary Change, 414 30(3-4), pp.271-307.

415 Vermeesch, P., Fenton, C.R., Kober, F., Wiggs, G.F.S., Bristow, C.S. and Xu, S., 2010. Sand residence 416 times of one million years in the Namib Sand Sea from cosmogenic nuclides. Nature 417 Geoscience, 3(12), pp.862-865.

418 Webb, N.P., McGowan, H.A., Phinn, S.R., Leys, J.F. and McTainsh, G.H., 2009. A model to predict land 419 susceptibility to wind erosion in western Queensland, Australia. Environmental Modelling \& 420 Software, 24(2), pp.214-227.

421 Willeit, M., Ganopolski, A., Calov, R. and Brovkin, V., 2019. Mid-Pleistocene transition in glacial cycles 422 explained by declining $\mathrm{CO}_{2}$ and regolith removal. Science Advances, 5(4), p.eaav7337.

423 Winter, T.C., 1999. Relation of streams, lakes, and wetlands to groundwater flow systems.

424 Hydrogeology Journal, 7(1), pp.28-45. 


\section{Supplementary Files}

This is a list of supplementary files associated with this preprint. Click to download.

- Kalaharisupplemanterydata.xlsx 